\title{
Gender Differences in the Usage of Speech Act of Promise among Moroccan Female and Male High School Students
}

\author{
Ilham MALKI ${ }^{1}$ \\ ${ }^{1}$ Ilham MALKI: PhD student, the English Department, Studies in Language, Culture, and Society Research Unit, \\ Mohamed V University, Rabat, Morocco. \\ Correspondence: Ilham MALKI, Ilham MALKI: PhD student, the English Department, Studies in Language, Culture, \\ and Society Research Unit, Mohamed V University, Rabat, Morocco.
}

Received: December 28, 2021

Accepted: January 27, $2022 \quad$ Available online: February 3, 2022

doi:10.11114/ijsss.v10i2.5472

URL: https://doi.org/10.11114/ijsss.v10i2.5472

\begin{abstract}
The study aims at examining and analysing speech act of promise used by male and female Moroccan high school students. Research studies conducted on speech acts in different languages and cultures serve to provide an insightful understanding of intercultural communication. They substantially help in reaching over communicative differences among speakers of divergent languages, and accordingly lay the ground for addressing and handling issues that arise from intercultural miscommunication. This article is a research endeavour that seeks to fill the void that has been mentioned above. The core of this study is on a pragmatic-based analysis of the speech act of promising in Moroccan Arabic. More precisely, it targets identifying and investigating the widely utilized techniques of promise among male and female Moroccan high school students.

The data has been collected from questionnaires composed of 19 hypothetical real-life situations in Morocco. The respondents of the research have been Moroccan-Arabic native speaking students studying in three public high schools in Casablanca, Morocco. The sample consists of 60 male students and 60 female students belonging to the three high school levels: common core, first year, and second year of Baccalaureate. The analysis of the data has revealed that Moroccan high school students embark on six strategies while constructing promise utterances, namely, self-repetition, conditional promises that incorporate $\mathrm{Al}$ Istithna (exception) promises and if promises, swearing tactic, assurance-based expressions, self-praising attributions, and preferred adjacency pairs technique. Furthermore, the findings of this study have exhibited that there are significant differences in the use of those strategies among male and female Moroccan high school students as they perform the speech act of promising. It has been proven through the distinct use of promising strategies that both genders speak different languages. Unlike male respondents whose language seems to be assertive, adversarial, and strong, female respondents speak a language of support, politeness, cooperation, and social affiliation.
\end{abstract}

Keywords: speech act, promise, strategies, gender, Moroccan Arabic

\section{Introduction}

Within any linguistic system, neutrality is deemed to be in absentia. The production of a language is not only cognizant on delivering and sharing clusters of utterances, but it is dependent on delivering presumptions and presuppositions its consumers hold as well. Individuals are demanded to obtain a language and develop knowledge of availing the acquired language for communication purposes. Effective communication, then, requires a thorough knowledge of the language and its pragmatics. Languages are used with the primary objective of performing certain acts and functions. Therefore, the notion of speech acts emerges. As a basic tool to explore pragmatics, the speech act theory has been widely investigated in the field of first and second language acquisition studies.

It is argued that speech acts convey knowledge about social rules of and the world of a language's speakers. In this spirit, Frederking (2007) contends that " rules- shared beliefs, norms, and identities- have the form of speech acts.....These connections show that when agents perform speech acts, they necessarily invoke social rules. Speech acts have meaning only within an already existing structure of social rules" (p.7-8).

The basic tenet of the speech act theory, which has been dredged up from the pioneer works of John Austin (1962) and John Searle $(1969 ; 1975 ; 1976)$, is that speakers perform certain illocutionary acts by producing utterances (Loutfi, 2015). Such utterances tend to deliver specific communicative intentions, for instance request, apology, refusal, advice, 
promise, compliment, offer, thanking, complaining, and promise. Drawing on Austin's work, Searle (1967) set forth a further taxonomy of speech acts that are concisely presented below:

1- Assertives: acts that urge the speaker to hold beliefs that specific propositions are true.

2- Directives: acts that propel the interlocutor to perform an action.

3- Commissives: speakers commit themselves to a future course of actions.

4- Expressives: speakers express their emotional attitudes towards some previous actions.

5- Declarations: Speakers bring about changes of the reality in accordance with the propositional content of the declaratives.

The speech act of promise, which is the core of this study, delineates a declaration and commitment. The Oxford Lexico Dictionary defines a promise as "a declaration or assurance that one will do something or that a particular thing will happen". Black (1991), in his Dictionary of Law, defines a promise as " a declaration, verbal or written, made by one person to another for a good or valuable consideration, by which the promisor binds himself to do, or forbears some act, and gives to the promise a legal right to demand and enforce a fulfilment" (p.952). A further definition by Webster's Seventh New Collegiate Dictionary (1996) identifies a promise as " a declaration that one will do or refrain from doing something specified" (Cited in Flagg, 1998, p. 140). Fried (2015), on the other hand, specifies promising within a paradigm of moral obligation, and accordingly asserts that a promise is a verbal communicative practice that " puts the moral charge on a potential act" (p.9).

An essential feature that underlines the theory of speech act is the fact that a particular speech act can be performed through various ways. In this regard, Austin (1962) distinguishes between two pertinent classifications: explicit speech acts and implicit speech acts. While the former are direct, lucid, and incorporate performative verbs, the latter are indirect and ambiguous in the sense they do not subsume a performative verb.

In the same vein, research carried out to investigate speech act of promise argue that promise making should not be perceived exclusively within the context of performative utterances, such as "I promise" or "I hereby promise". Al Saffar and Abbas (2011) explain that promising can be invoked through several means like" shaking hands, giving money or giving a key to a safe containing money, or any other indirect expressions of promising" (p. 331).

Equally important, studies conducted within the field of gendered languages argue that there are differences between male and female in the daily communication practices. These differences stem out of cultural contexts and social norms that urge males and females opt for divergent communicative styles.

As has been previously stated, a promise is typically perceived as a promisor's commitment to perform a particular act in the future. This implies that when a promisor builds up their promises, they are enforced to fulfil them. Producing statements like "I will drop you to the airport tomorrow" or "I will certainly put you up in my house" are conceived in western countries as promises to which speakers are committed to fulfil. . However, it should be noted that for face-saving issues, western promisors would not engage in promise making unless they are categorically assured they are able to attain it. Therefore, utterances like "I will try, but I cannot promise you" or "I would like to borrow you my motorcycle, but I'm afraid I cannot" are not very common if the foreigner is not ascertained about the fulfilment of the promised affair. In low-context cultures, more precisely the Arab world, uncertainty about one's fulfilment of a promise is more frequently mitigated by the linguistic mitigating device of "InshaALLAH" translated into English "If God's

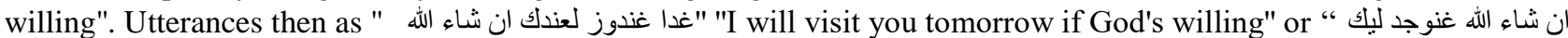
"لفلوس "If God's willing, I will arrange the money for you" are not perceived as authentic promises. Rather, they are received by Arabs, in general, and Moroccans, in specific, as conditional promises that underline the achievement of the promised acts only if Allah (God) wills. It is, then, due to these divergent perspectives that this study is designed to figure out promising strategies among Moroccans, more precisely among Moroccan high school students. This research, henceforth, is.. carried out to answer the following questions:

1- What are the primary strategies Moroccan high school student opt for to construct the speech act of promise?

2-Are there any gender differences in producing the speech act of promise?

This research has both theoretical and practical implications. Few Arab, and more specifically Moroccan studies, have been carried out to investigate speech act of promise. Therefore, the results of the study are expected to provide researchers with further significant references about the target topic and fill the gap in the academic literature of speech act theory. Practically speaking, identifying the various strategies through which Moroccan high school students establish their promising utterances helps to get an insightful cultural understanding about the target community and their intentions while performing the act of promise. Equally important, the results of the study are of significant importance at the linguistic level as they enrich the knowledge about the different languages, which accordingly 
contribute to the best understanding of the Other' s language system.

\section{Purpose of the Study}

The fundamental objective of this research study is to examine the primary strategies and tactics that are utilized by Moroccan high school students to set forth promise utterances. Towards this objective, the speech act of promise in Moroccan Arabic is analysed. The findings of this study assist to brush away cultural misunderstandings since research on speech act theory helps to inform individuals of different cultures of the pragmatic failures that are likely to emerge in social and pedagogical settings. As has been stated earlier, very few Arab studies, with a difficulty to find a single Moroccan study, have dealt with the issue of speech act of promise in Moroccan context. Furthermore, while these studies have been held to examine speech act of promise from a general perspective, almost no a single identifiable study has been designed to investigate the mechanism of speech act of promise by Arab high school students. Therefore, the findings of this study will contribute to and are considered as an essential reference for researchers who are interested in examining the speech act of promise within Moroccan culture. Furthermore, the current study is significant because it lays its findings within the paradigm of two different cultures that highlights 'gender' as a criterion of differences.

\section{Review of Related Literature}

\subsection{Speech Act of Promise}

Promise is a commissive speech act whose illocutionary force is that the issuer of the promise carries out a specific act in the future to the profit of the addressee (Searle, 1969). Once a promise is issued, the speaker commits to the fulfilment of the promised act. Syntactically speaking, the speech act of promise is I+ verb+ propositional content as in "I promise to visit you. More often, the speech act of promise is constructed using the performative verb of 'I promise'. However, promissory utterances can be relayed without the use of performative verbs and are considered performative acts. Austin (1962) distinguishes between performative utterances, as including what he labels primary performatives and explicit performatives of promising. For example:

$$
\begin{aligned}
& \text { E.g. I shall get you a dress } \\
& \text { E.g. I promise that I shall get you a dress. }
\end{aligned}
$$

While the first sentence embodies a primary performative, the second utterance is an explicit performative as it includes the verb promise. Although the both statements act the same speech act, namely promise, they are semantically different. Explicit performatives are more precise in meaning than primary performatives.

However, Searle (1969) suggests nine requirements that stand for the validity of promise speech act. These requirements are listed below:

1- Both the speaker and hearer have to understand the language and the commitment conveyed by the speech act.

2- The speaker expresses the proposition.

3- The promise utterance predicates a future action to be performed by the speaker himself and not anyone else.

4- The hearer desired the promise future action fulfils for them and the hearer is fully conscious of their desire.

5- It is not clear that the promised future action would have been attained by the speaker preceding the issuing of promise.

6- The speaker intends to do the future action and believes it is possible for them to do the act.

7- The speaker intends that the promised utterance will place him under the moral obligation to fulfil it.

8- The promised utterance is a semantic indicator that expresses and conveys the intended promise, which is perceived by the hearer as such.

9- The promise is sincerely and correctly produced merely if all other requirements are available (Searle, 1969, p. 5761)

\subsection{Functions of Promise}

Promise is best perceived as a social practice that seeks to induce trust (Alles, 2018). Howe (2013) defines trust as an assessment that is recognizant on some or all of the following components:

-Sincerity: (Do people mean what they say?)

-Competence: (Do people have the skills/experience to fulfil the promise?)

Reliability: (Part of competence- do they deliver on time and to agreed standards?) 
-Involvement: (Attuned to others concerns as well as own.) (n.p)

It seems crucial that authentic trust, as a basic component in the process of promise making, smooths the ground for and assists the progress of cooperation and social collaboration between the conversationalists (Fischer, et al, 2017). The process of enacting a promise is, therefore, a systematic process that allows the satisfaction of human needs which highly connected to the two basic components of "information interest" and "authority interest" (Owens, 2006). Owens (2006) defines "interest information" as an interest in "information about what will happen" (p. 51). In another way, individuals take promises seriously because they want to get information about how social entities will behave. "Authority interest", on the other hand, epitomizes the moral authority the promisee holds over the enacted promise. This designates that authority interest confers the promisee the right to demand the achievement of the promised act. For example, if I promise my child to have a toy, I am compelled to get him a toy unless he liberates me from my promise.

In the same vein, Al Saffar and Abbas (2015) assert the social function of the speech act of promise. They suggest that promises are deemed to perform a persuasive function. They are used to "convince others of the speaker's good intention, to soften the incensement of the addressee, to give satisfaction and pleasure to others, and to express someone's approval or rejection" (332).

To get an insightful understanding of how promises function, Beller and Bender (2017) propose a multidimensional framework. This framework consists of five levels: motivational, linguistic, deontic, behavioural, and emotional level. Beller and Bender (2017) argue that promises are complicated forms of social interaction between two individuals who hold goals, expectations, and concerns about the gains and costs. The promises can be conveyed in a direct or indirect manner through linguistic strategies. They similarly contend that promising utterances binds the promisor to collaborate and that "the subsequent behaviours of speaker and addressee have a high potential for eliciting emotional reactions" (p.3).

\subsection{Gender and Speech Act of Promise}

Within the field of sociolinguistics, the concept of gender is closely affiliated with social paradigms that are primarily borne upon socio-cultural conditions, such as of biological gender, gender social roles, and gender social norms. The literature that addresses the impact of gender on languages reveals that females and males speak different languages (Maltz and Borker, (1982); Tannen (1990); Gray (1992)). Maltz and Borker (1982), for example, contend that males and females belong to different cultures that urge the development of different communicative competences. The different cultures of males and females have an integral part in evolving dissimilar cultural expectations about talk. In this regard, Maltz and Borker (1982) postulate that while female individuals talk to establish and sustain close relationships, males apperceive talk to deliver information and fulfil the desired tasks.

Gender differences have been also investigated in the speech act of promise, more specifically, with regard to promise making and promise keeping. A study conducted by Huang and Hund (2013) demonstrates that gender differences exist in behavioural integrity with some variation in context. By behavioural integrity, the researchers designate the level of consistency of one's words and actions. The study, then, reveals that males tend to show a high level of behavioural integrity than women in public compared to the lower level of behavioural integrity in private context. Another study by Arief and Mugableh (2013) affirms that Jordanian females and males demonstrate differences while making promises. Jordanian women have a tendency towards the use of body-expressions once they produce their promising utterances. Since their language is highly associated with attachment and intimacy, Jordanian females' speech is typically inclusive, indirect, and argumentation-free. By contrast, men issue promising utterances that reflect a language of status and independence. Lazarev and Pravikova (2003) also address how language embodies and maintains gender attitudes through speech act of promise and warranties. They expound that unlike men who promise more often, women rarely use explicit performatives to issue their promise constructs.

By contrast, other studies that systematically dealt with gender differences in promise keeping argue that males and females show no differences in the motives for promise giving. For example, a recent study conducted by Kleinknecht (2019) confirms the absence of any gender disparities related to promise giving or to the motives for promise keeping. Further studies that examine factors influencing promise keeping demonstrate that female subjects exhibit as much trustworthiness as men (Chaudhuri and Gangadharan (2003); Heinz, et al, (2008); Buchan, et al, (2012)).

To keep a promise is substantially related to sincerity and honesty. Studies conducted by Muehlheusser, et al (2015), Grosh and Rau (2017), and Capraro (2018) recognise gender differences in honesty and truth telling. They ascertain that women are more likely to be honest and tell truth than men.

\section{Research Design}

The present study aims at identifying the most common strategies Moroccan high school students deploy to make 
promises. It examines the syntactic level of the Moroccan Arabic promising utterances of the target subjects. Therefore, the Austinian framework of speech act (1962) is adopted for this research study. Variables of age, gender, and educational level are considered in this study. The researcher, then, identifies the various tactics Moroccan male and female students opt for to set up their promises. Following the Lakoffian (1975) features of women's language, the researcher investigates whether Moroccan male and female high school students exhibit any different linguistic tactics while performing the act of promising. Examples of features that are targeted in this study are presented below:

- Tag questions

-Lexicality

-Hedging

-Empty adjectives

-Intensifiers

- Super polite forms

-Indirect requests

- Hyper correct grammaticality

It should be noted that the study does not consider the feature of rising intonation since this data of this study has been collected by means of a questionnaire. To meet the objectives of this research, a 19 items questionnaire has been designed and administered to a sample of 120 Moroccan high school participants ( 60 females and 60 males) from public schools in Casablanca, Morocco. The questionnaire seeks how native Moroccan Arabic speaking high school students make promises and whether there are any differences in the manner female and male respondents issue promising utterances. Henceforth, the data has been collected in Moroccan Arabic and then translated into English.

\section{Participants and Selection Method}

The core of this research study is to identify the primary strategies Moroccan high school students utilize to perform the act of promise. It also prowls for figuring out whether male and female respondents incline towards different strategies while producing promise utterances. The research study seeks to provide a concise answer and examine the research questions from a holistic perspective through the obtainment and analysis of the collected data. To this end, the study brings a combination of qualitative and quantitative approaches with the primary objective of gaining insightful understanding of the research problem.

Since it is impossible to measure every individual point in the population of high school students, the present study takes up a stratified sampling method. This method enables to attain a sample population that better represents the entire population under study. This study, then, chooses Moroccan high school students, in three public high schools in Casablanca, Morocco, as a representative sub-population sample to ensure the random, proportional sample of the students' subpopulation. The participants of this study are specifically composed of native speakers of Moroccan Arabic. 120 samples have been selected to respond to the designed questionnaire. The sample population has been divided equally 60 males and 60 females belonging to the three levels of high school education, namely the common core, first year of Baccalaureate, and second year of Baccalaureate. Below is the chart that represents the profile of the sample members:

\begin{tabular}{|l|c|c|c|}
\hline \multirow{2}{*}{ Respondents' Category } & Gale & \multirow{2}{*}{ Age } \\
\cline { 2 - 4 } & \multicolumn{2}{|c|}{ Female } & $\mathbf{1 6 - 1 9}$ \\
\hline Common Core Students & $\mathbf{2 0}$ & $\mathbf{2 0}$ & $\mathbf{1 7 - 2 1}$ \\
\hline $\begin{array}{l}\text { First year of Baccalaureate } \\
\begin{array}{l}\text { Second year of } \\
\text { Baccalaureate }\end{array}\end{array}$ & $\mathbf{2 0}$ & $\mathbf{2 0}$ & $\mathbf{1 8 - 2 3}$ \\
\hline
\end{tabular}

\section{Data Collection and Instrumental Tool}

The primary objective of this study is to explore strategies through which Moroccan high school students elicit promise utterances. With this objective in mind, all 120 Moroccan high school students have been administered and asked to fill in a Discourse Completion Test (DCT) of Beebe, et al (1990) consisting of 19 unreal situations to which the participants have been requested to elicit promising statements.

Notably, the eliciting tool adopted in the current research is claimed to exhibit some limitations regarding the short responses, simple wording, and thin elaboration (Billmyer and Varghese, 2000). However, Nurani (2009) asserts that DCT remains more practical than other major eliciting data instruments. In this regard, Nurani (2009) proclaims that DCT "allows researchers to collect a large amount of data in a relatively short time. Furthermore, DCT creates model responses, which are likely to occur in spontaneous speech" (667). 


\section{Findings and Discussion}

The analysis of the collected data for the current research has demonstrated that Moroccan high school students tend to use various strategies to launch the speech act of promise. Such strategies are discussed in the forthcoming sections.

\subsection{Moroccan High School Students Strategies of Speech Act of Promise}

This section analyses and discusses the findings of the collected data. It seeks to identify the fundamental strategies Moroccan high school students settle on to disperse promising utterances. The results of the data reveal that Moroccan high school students have opted for 6 strategies to perform the speech act of promise. Each strategy is presented in a percentage in the following chart:

\begin{tabular}{|l|c|c|}
\hline \multicolumn{1}{|c|}{ Promise Strategy } & Frequency & Percentage \\
\hline Self-Repetition & $\mathbf{4 3 0}$ & $\mathbf{2 4 . 5 7}$ \\
Conditional Promises & $\mathbf{3 8 0}$ & $\mathbf{2 1 . 7 2}$ \\
Reassurance Expressions & $\mathbf{3 0 0}$ & $\mathbf{1 7 . 1 4}$ \\
Swearing Phrases & $\mathbf{2 7 6}$ & $\mathbf{1 5 . 7 7}$ \\
Self-Praising Attributions & $\mathbf{2 0 0}$ & $\mathbf{1 1 . 4 3}$ \\
Adjacency Pairing & $\mathbf{1 6 4}$ & $\mathbf{9 . 3 7}$ \\
\hline
\end{tabular}

\subsubsection{Self-Repetitions}

The results of this study have shown that $24.57 \%$ of the total amount of the promise strategies collected for this research falls within the range of self-repetition strategy. By definition, self-repetition involves "a deliberate, ostensive attempt to reproduce the form of a communicative act that has been produced previously" (Jackson, 2016, p.10). Some Moroccan participants in this study tend to evoke statements that repeat their prior text while making promises. Repetitions are generally perceived to embed redundancy and sloppiness, and reflect incompetence of the speaker's speaking skills (Shimanoff and Brunak, 1977). However, not all repetitions are pointless; some repetitions flout the Gricean maxim of quantity to enforce certain social functions, more particularly initiating repairs, seeking confirmation and clarification, and displaying emotional attitudes (Kim, 2002).

With regard to the current study, the self-repetitions Moroccan high school students have produced while engendering promise utterances serve two pragmatic functions. Let us consider the following examples:

\begin{tabular}{|c|c|c|}
\hline DCT Item & Moroccan Arabic Promise Utterance & English Translation \\
\hline Situation 13 & صافي صافي غادي نسلفك لكتاب & Ok, ok, I will lend you the book \\
\hline Situation 5 & هاني هاني، دقيقة و غنصيفط ليك لإيميل & $\begin{array}{l}\text { Here I am, here I am, one minute and I will send you the } \\
\text { e-mail }\end{array}$ \\
\hline Situation 9 & لكيد ميلاد هي لكلمة غادي ندير ليك لعيد ميلاد هي غادي ندير ليك & $\begin{array}{l}\text { A promise is a promise. I will make a birthday party for } \\
\text { you means I will make a birthday party for you. }\end{array}$ \\
\hline
\end{tabular}

Notwithstanding the fact that the above self-repetitions aim at performing the illocutionary force of promise, they are established by the promisor to afford agreement and confirmation. The repetends in Situation (13) " ok, ok", situation (5) "Here I am, here I am", and situation (9) " A promise is a promise. I will make a birthday party for you means I will make a birthday party for you" are strategically constructed to reveal the promisor's approval and sincere intention to undertake the promisee's desired act. Equally important, the above repetitions pile out as clear-cut conversational utterances that seek to blot out doubts the promisee may evolve against the fulfilment of the promise.

Furthermore, the analysis of the data discloses a further conversational function of the promisor's self-repetition, more precisely showing irascibility and annoyance. This is clearly elucidated in the forthcoming examples:

\begin{tabular}{|c|c|c|}
\hline DCT Item & Moroccan Arabic Promise Utterance & English Translation \\
\hline Situation 7 & ولبا راسي، صافي، وا صافي، راه غنعطيك طوموبيل. مالك صدعتي & $\begin{array}{l}\text { Ok, ok, I will lend you the car. Why are you causing me a } \\
\text { headache? }\end{array}$ \\
\hline Situation 3 & غندوز لِندلك هي غندوز لعندك بلا متبقى ترابي علبا & $\begin{array}{l}\text { I will visit you means I will visit you. Stop rapping over } \\
\text { my head }\end{array}$ \\
\hline Situation 15 & بلا ماتبقى مبرزطني، كتلبك غنعاو نك تصاوب تمرينك & $\begin{array}{l}\text { Stop disturbing me, I promised to help you doing your } \\
\text { homework. }\end{array}$ \\
\hline
\end{tabular}

The repetends or the repetitive utterances in each of the above situations are not predominantly constructed to provide agreement or confirmation, though it is the case; rather, they are produced in a manner that reveals the promisor's irritation and annoyance against possible intolerable behaviour from the side of the interlocutor. The promisors, in the above examples, express directly they cannot bear the seemingly discomfort and face-threatening acts they receive from the promises. This is clearly elucidated in the criticising phrases that objurgate the interactants and violate the politeness theory, as in situation (7): " Why are you causing me a headache?", situation (3): " Stop rapping over my head", and situation (15): " Stop disturbing me". 


\subsubsection{Conditional Promises}

The analysis of the data has revealed that conditional promises amount to $21.72 \%$ of the gathered data for this research. Couch, et al (2007) define a conditional promise as "a promise that is held by an agent, but whose validity is contingent upon the validity of other stated promise" (98). Such a type of promise is culture-determined for Arabs in general. More specifically, conditional promises, in Arab countries, are bound by ethical, religious, and social traditions. As a matter of fact, the results of this study have highlighted two primary ranges of conditional promises, more precisely, "Al Istithna (exception) promises" and "if promises".

\subsubsection{Al Istithna Type Promises}

Osman and Jalil (2013) expound that an important principle that characterizes promise making in Islam is the usage of Al Istithna that relies on the deployment of "InshaALLAH" and its variants. "InshaALLAH" is an Arabic phrase that can be translated into English as "God willing" or "if God wills". Examples of Al Istithna type promises that have been discerned while analysing the data are examined below:

\begin{tabular}{|c|c|c|}
\hline DCT Item & Moroccan Arabic Promise Utterance & English Translation \\
\hline Situation 12 & إن شاء الله غادي ندير ابابا جهدي و الكمال على الله & $\begin{array}{l}\text { If God wills, I will do my best father and the rest is up to } \\
\text { ALLAH }\end{array}$ \\
\hline Situation 10 & إلا بسر الله غادي نزيدك فالثهرية & If ALLAH makes it easy, I will raise your salary \\
\hline Situation 8 & إلا بغا الله غادي ندوز معاك رمضان & $\begin{array}{l}\text { With the willingness of ALLAH, I will spend Ramadan } \\
\text { with you }\end{array}$ \\
\hline Situation 1 & بإذن الله وبعونه غادي نشري ليكوم الحولي هاد لعام & $\begin{array}{l}\text { With the permission and aid of ALLAH, I will buy the } \\
\text { sheep this year. }\end{array}$ \\
\hline
\end{tabular}

Having investigated the above instances, the researcher notices that Moroccan high school students opt for expressing

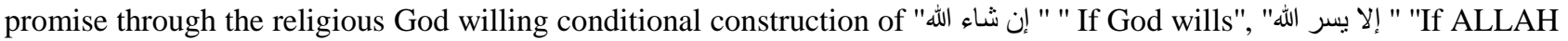
makes it easy", "إلا بغا الله " "With the willingness of ALLAH", and " بإذن الله وبعونه " "With the permission and aid of ALLAH". What makes the illocutionary force of the above Istithna phrases a promise is the fact that they are followed by the Moroccan Arabic particle of futurity " غادي " " which is similar to the future English modals 'will' or 'shall'. It is worth noting that the tendency of using God willing formulaic expressions arises from the Muslims' sacred belief that every single action in this universe is under the complete willingness and control of ALLAH. In Islam, the use of Al Istithna phrases while making promises is highly recommended. According to Surah Al Kahf: The Cave, verses 23-24: "

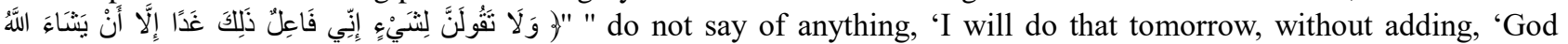
willing" (Translated by Abdel Haleem,2004, p. 184-185).

The above verses urge Muslims to use Al Istithna phrases, more specifically "InshaALLAH" to avoid the sin of breaking the promise. However, it should be noted that Al Istithna promises bear up a subtle pragmatic deviation among Arabs in general. It has become quite common for many Arabs, among whom Moroccans are no exception, to use "InshaALLAH" and its variants as an evasive strategy. Let us consider the following examples:

\begin{tabular}{|c|c|c|}
\hline DCT Item & Moroccan Arabic Promise Utterance & English Translation \\
\hline Situation 2 & 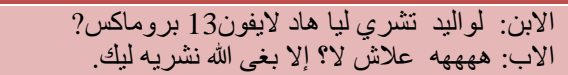 & $\begin{array}{l}\text { Son: Father, will you buy me iPhone } 13 \text { Pro Max? } \\
\text { Father: hhh, why not. If ALLAH wills I will buy it for you }\end{array}$ \\
\hline Situation 16 & 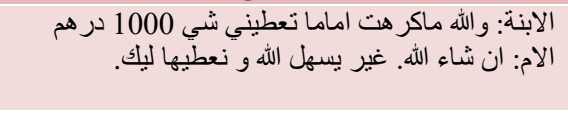 & $\begin{array}{l}\text { Daughter: I really hope you give me } 1000 \mathrm{Dh} \text { mother. } \\
\text { Mother: InshaALLAH, If ALLAH makes it easy, I will } \\
\text { give it to you. }\end{array}$ \\
\hline
\end{tabular}

In the above promising utterances, the promisors tend to avoid the binding aspect of their promises by prefacing their promises with Al Istithna phrases of "ان شاء الله. غير يسهل الله" InshaALLAH, If ALLAH " إلا بغى الهاء "If ALLAH wills" and makes it easy". Equally important, the use of Istithna expressions as the examined one in situation (2) is negatively interpreted in the sense that it is preceded by a laughter; which accordingly signifies that the promisor is not serious about his intention to carry out the promise, and that he merely wants to end the conversation.

\subsubsection{If-Promises}

The second type of conditional promises that has been identified while analyzing the data of this study is 'if-promises'. Instances that illustrate this type of promises are provided below:

\begin{tabular}{|c|c|c|}
\hline DCT Item & Moroccan Arabic Promise Utterance & English Translation \\
\hline Situation 6 & إلا نجحتي نشري ليك سيارة & If you pass the exam, I will buy you a car. \\
\hline Situation 14 & ام ام، كون تخليني ندوز الويكاند فدارك فكابو نكرو نسلفك & $\begin{array}{l}\text { Um, um if you allow me to spend the week end in your } \\
\text { house in Cabo Negro, I will lend you the money }\end{array}$ \\
\hline Situation 17 & عاوني نعاو نك & Help me, I will help you \\
\hline
\end{tabular}

The speech act of promise in the above situations is implicitly identified by the use of conditional utterances. Such utterances initiate with the Moroccan Arabic particle 'إل', in situations (6) and 'كون' as in situation (14). They are also expressed by the imperative verb as 'عاوني' 'help me' in situation (17). Song, et al (2009) affirm that conditional promises 
seek out a behavioural change. In prowling after their objectives, the addressers in the above situations issue conditional statements with the primary intention of changing the behaviours of the addresses. For instance in situation (6), a father yearning for his daughter's success is informing his daughter ' إلا نجحتي نشري ليك سيارة' 'If you pass the exam, I will buy you a car'. Excited by the surprising reward, the daughter may be encouraged and determined to accomplish his condition. Henceforth, the conditional aspect of the above promising statements is reflected in the fact that the liability to fulfil the promise depends upon the achievement of the proposition in the 'If-clause'. In other words, conditional promises involve bilateral cooperation of both the addresser and addressee. Both participants have to decide whether or not to collaborate. It is worthy to mention that 'if promises' serve the same underlying pragmatic function of Al Istithna promise utterances. By prefacing the promise statement with if-clauses, the promisor tends to avoid the binding aspect of his statement.

\subsubsection{Conversational Swearing}

Along with self-repetition strategy and conditional promising, the results of the study have demonstrated that some Moroccan high school students tend to preface their promising utterances with a swearing expression. This strategy represents $15.77 \%$ of the total of promising utterances in this study. From an Islamic perspective, swearing refers to a speech act through which a person 'binds her/himself to do or not a certain specific physical or juridical act, by invoking the name of God or one of the divine attributes' (Abdel-Jawad ,2000, p.218), such as the scared Quran or the holy places of Mekka. Swearing is a prevalent communication behaviour among Arabs in general, and Moroccans, in particular. Abdel-Jawad (2000) claims that swearing accomplishes various communicative purposes, namely, confirming claims, emphasizing promises, denying accusations, declining offers and invitation, persuading, and intensifying threats or warnings. In the same regard, Ansari-Naim (2016) explains that swearing as a speech practice serves to validate and inflict more credibility to the verbal utterances' pragmatic context. Alternatively stated, when a person swears, his/her swearing statement is deemed to be taken as the very truth by the counter-part. Swearing, then, embeds the highest levels of speakers' credibility, truthfulness, and commitment. Let us now consider the following examples:

\begin{tabular}{|c|c|c|}
\hline DCT Item & Moroccan Arabic Promise Utterance & $\begin{array}{c}\text { English Translation } \\
\end{array}$ \\
\hline Situation 13 & و الله حتى غادي نسلفك لكتاب & I swear, I will lend you the book \\
\hline Situation 15 & دالرياضيات بالله العلي العظيم حتى غنعاونك تصاوب التمارين & $\begin{array}{l}\text { I swear to God Almighty, I will help you in doing the } \\
\text { maths homework. }\end{array}$ \\
\hline Situation 8 & وحق الله وحق رب الكعبة حتى غادي ندوز معاك رمضان & $\begin{array}{l}\text { By the truth of ALLAH, by the truth of the God of the } \\
\text { honourable Al Kaaba, I will spend Ramadan with you. }\end{array}$ \\
\hline
\end{tabular}

Having examined the above examples, the researcher notices that swearing statements produced by the subjects follow the following structure:

\section{Swearing Particle + Swearing Referent+ Speech act of}

The structure of the above swearing statements is clearly demonstrated in the chart below

\begin{tabular}{|l|l|l|l|}
\hline Situation & Swearing Particle & Swearing Referent & Speech Act \\
\hline -Situations 8 & Waaw alqasam & - Allah & -Promising \\
-Situation 13 & - wa/ & -Divine Place & -Promising \\
-Situation 17 & $\begin{array}{l}\text { or } \\
\text { Kaaf alqasam +verb } \\
\text { /ka/ }\end{array}$ & Allah & -Promising \\
\hline
\end{tabular}

By prefacing the promising statements with a swearing formula, Moroccan high school students express their full commitment and their sincere intention to fulfil what they pledge. In that manner, promissory utterances have gotten a binding aspect, since they invoke the most solemn authority and revered places for Muslims: the Almighty ALLAH and the Kaaba.

\subsubsection{Assurance-Based Promises}

Furthermore, the analysis of the data identifies a further distinct range of expressions employed by the participants of the study to forge their promises. These expressions are involved to induce a feeling of assurance. Austin (1962) proposes that promises and assurances 'involve giving others one's word or offering a guarantee" (Cited in Lawlor, 2014, p.12).

Assurance-based promises constitute $17.14 \%$ of the totality of the data collected for this research. This type of conversational strategies, assurance strategies, has dual objective: to assert the truthfulness of a specific state of affair and to commit to fulfil what has been just uttered. Let us examine the following examples: 
DCT Item

Situation 13

Situation 7

Situation 17
Moroccan Arabic Promise Utterance

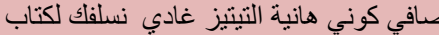

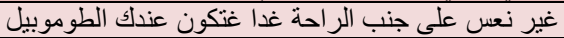

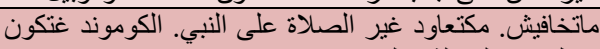
عندك غدا الغز الة ديالي
English Translation

Ok, be assured, cute, I will lend you the book

Don't worry, tomorrow you will receive the car

Don't be afraid. Only prayers upon Mohammed the prophet are repeated. You will receive your order tomorrow my beautiful.

As can be seen, before getting engaged in promise making, Moroccan high school students initiate their utterances with expressions such as 'صافي كوني هانية' 'Ok, be assured', 'غير نعس على جنب الراحة', which can be literally translated into English 'sleep on the comfort side' and semantically means 'Don't worry', and 'ماتخافيش. مكتعاود غير الصلاة على النبي' 'Don't be afraid. Only prayers upon Mohammed the prophet are repeated', to convey a sense of assurance to their interlocutors'. By supporting their promises with the above body of assurance expressions, the promisors tend to express their thorough readiness and commitment to attain the desired goals with the perlocutionary intention of tossing out worries or doubts the interlocutors may develop about the fulfilment of the desired acts.

\subsubsection{Self- Praising Attributions}

During the analysis of the data of this study, the researcher has come across another type of strategies Moroccan high school students use to create promising utterances. This strategy includes phrases that praise and enhance the promisor's self. I define self-praising in terms of the tendency to sustain and enhance positive self-representation. Typically, social human beings do not spare any effort to promote positive feedback with regard to their competence, superiority, and reputation. To put it differently, regardless of the social context, people tend to engage in conveying and fostering positive self-conceptions that simultaneously underestimate the other.

As far as the core of this study is concerned, self-praising attributions consist of $11.43 \%$ of the total amount of the collected data. Now, let us study some illustrating examples:

\begin{tabular}{|c|c|c|}
\hline DCT Item & Moroccan Arabic Promise Utterance & English Translation \\
\hline Situation 11 & ر اه كلمة الرجال غادي تلعب معانا الماتش الجاي & It is the men's word, you will play with us the next match \\
\hline Situation 7 & ندوز ليكي الطوموبيلي راكي تما. فين عمري خويت بيك. غدا & $\begin{array}{l}\text { Ok, rely on me. I have never let you down. Tomorrow you } \\
\text { will get the car }\end{array}$ \\
\hline Situat & غدي ندوز معاك رمضان لهنبانهاش. غدي ندوز معاك رمضان هي & $\begin{array}{l}\text { I do not change my words. I will spend Ramadan with you } \\
\text { means I will spend Ramadan with you. }\end{array}$ \\
\hline
\end{tabular}

The speakers in the above situations place a focus on their ability to bring about the desirable events expressed in the sentences. This is clearly exhibited through the overinflated perceptions they attach to their character and skills. The promisors in the above sentences underline values of manhood as in situation (11) 'راه كلمة الرجال' 'It is the men's word',

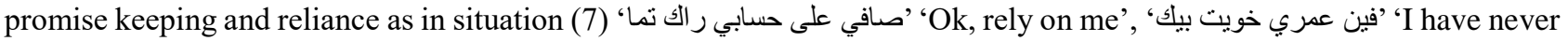
let you down', and commitment as in situation (8) 'الهررة لي تتكولها مكنبدلهاش 'I do not change my words'. Whether or not those values reflect the real personality of the promisor, they serve to influence the other by fending off their doubts and concerns, and ultimately lead them to perceive the promisor as a committed person. Equally important, self-praise can be recognised on accounts of Brown and Levinson (1987) theory of positive face that emerges out of the speaker's desire to be admired and sustain positive self-image.

\subsubsection{Preferred Adjacency Pair}

The results of the study showed that a further conversational strategy Moroccan high school students incline to while making promise is through establishing a preferred adjacency pair. The latter constitutes $9.37 \%$ of the total amount of promise statement collected for this research. Hutchby and Woffitt (1998) designate adjacency pair as "certain classes of utterances conventionally come in pairs" (p.39). Acts in adjacency pairs are organized within a first-pair part and second-pair part. Each first-pair part bears an expectation of a second-pair part, which is designated as a preference organization. The latter may entail preferred or dis-preferred responses. To get an understanding of how preferred adjacency pair has been handled as a promise making strategy for the Moroccan participants in this study, let us consider the following examples:

\begin{tabular}{|c|c|c|}
\hline DCT Item & Moroccan Arabic Promise Utterance & English Translation \\
\hline Situation 4 & الت: كنو اعدك مانكذبش مرة اخدي اخدى اعمرك باقي تكذب عليا & $\begin{array}{l}\text { Teacher: I want you to promise me never lie to me again } \\
\text { You: I promise not to lie again }\end{array}$ \\
\hline Situation 18 & انت: طبعا نوصلك صاحبك: توصليني الزوينة ديالي للطبيب غدا؟ & $\begin{array}{l}\text { Your friend: Will you drop me to the doctor cabinet } \\
\text { tomorrow? } \\
\text { You: I will drop you my beautiful. }\end{array}$ \\
\hline Situation 19 & صاحبتأك: تسلفيني القفطان ديالك نهار السبت؟ & $\begin{array}{l}\text { Your friend: Will you lend me your Caftan next Saturday? } \\
\text { You: Certainly, I will lend it to you. }\end{array}$ \\
\hline
\end{tabular}


As can be seen, the above adjacency pairs are constructed in a question-answer structure. In the first-pair part of each adjacency pair, the addressee seeks to fetch a promise from the interactant. Luckily, those seeking promise utterances were followed by a preferred second pair part whereby the promisor committed to fulfill the favoured outcome. The promisor's agreement with the question first pair part is clearly manifested through the use of the adverbs ' " 'of course', 'بالتأكيد' 'certainly' and the production of phrases that echo some phrases the promise has just articulated.

\subsection{Gender Differences and Promise Making}

This section aims at finding out whether Moroccan male and female high school students manifest any linguistic differences while establishing promising utterances. In order to answer this question, the researcher considers the Lakoffian features that distinguish women's language (see section 4: research design). The results of the data are presented in the following chart:

\begin{tabular}{|l|c|c|}
\hline \multicolumn{1}{|c|}{ Lakoff's Features } & Male Use & Female Use \\
\hline Precise Color Terms & $0 \%$ & $0 \%$ \\
\hline Lexical Hedges or Fillers & $15 \%$ & $20 \%$ \\
\hline Tag Questions & $0 \%$ & $0 \%$ \\
\hline Empty Adjectives & $1 \%$ & $5 \%$ \\
\hline Intensifiers & $2 \%$ & $3 \%$ \\
\hline Hyper-correct Grammar & $1 \%$ & $20 \%$ \\
\hline Super Polite Forms & $12 \%$ & $12 \%$ \\
\hline Strong Swearing Words & $2 \%$ & $2 \%$ \\
\hline Emphatic Stress & $12 \%$ & \\
\hline
\end{tabular}

As is clearly shown in the table, the findings of the study are consistent with Lakoff (1975)'s findings. The Moroccan female high school students' responses validate most of the features suggested by Lakoff(1975). For example, with regard to the use of hedging and fillers, Moroccan female subjects score $20 \%$ than men who score $5 \%$ only. Some illustrations of the hedges and fillers female respondents use while creating promising utterances are provided in the chart below:

\begin{tabular}{|c|c|c|}
\hline DCT Item & Moroccan Arabic Promise Utterance & English Translation \\
\hline Situation 6 & عرفتي إلا نجحتي نشري ليك سبارة & You know if you pass the exam, I will buy you a car. \\
\hline Situation 14 & ام ام، كون تخليني ندوز الّويكاند فدارك فكابو نكرو نسلفك & Um, um I don't have a penny, If I did, I would give you \\
\hline Situation 19 & اللتبة: هانتي كنعتاقد غنسلفك القفطان و الصباط باش تجيك & $\begin{array}{l}\text { You: Well, I think I will lend you the Caftan and the shoes } \\
\text { so as you will look gorgeous }\end{array}$ \\
\hline
\end{tabular}

In the above examples, the female respondents initiate their promising utterances with hedges and fillers, namely 'you know', 'Um um', and 'well, I think'. The use of these linguistic features serves to designate a lack or the promisor's desire not to convey a thorough commitment to the expressed propositions in the above statements. Therefore, the use of hedging and fillers is deemed to be a precautionary measurement to protect the self from the negative effect of their statements.

As far as the empty adjectives are concerned, the findings demonstrate that female respondents use empty adjectives more than male respondents:

\begin{tabular}{|c|c|c|}
\hline DCT Item & Moroccan Arabic Promise Utterance & English Translation \\
\hline Situation 17 & ماتخافيش. مكا الغز الة ديالي غير الصلاة على النبي. الكوموند غنكون & $\begin{array}{l}\text { Don't be afraid. Only prayers upon Mohammed the } \\
\text { prophet are repeated. You will receive your order } \\
\text { tomorrow my gorgeous. }\end{array}$ \\
\hline Situation 18 & انت: طبعا نوصلك الزوينة ديالي & You: I will drop you my beautiful. \\
\hline
\end{tabular}

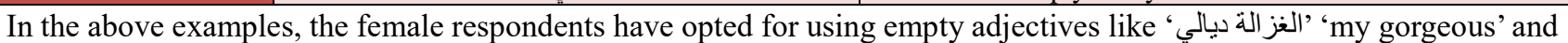
'الزوينة ديالي' 'my beautiful' at the end of their promising utterances. Such adjectives as Lakoff (1975) explains are devoid of meaningful content, but they are used here to induce affective effect towards the interactants.

Furthermore, the analysis of the data has revealed that intensifiers are more frequent in the females' promising utterances. The results have shown that female high school students score 5\% of the use of intensifiers. For example,

\begin{tabular}{|c|c|c|}
\hline DCT Item & Moroccan Arabic Promise Utterance & English Translation \\
\hline Situation 6 & نشري ليك سيارة مزيان مزيان ابنتي مكنبدلش هدرتي ـإلا نجحتي & $\begin{array}{l}\text { You know me very well very well my daughter. I do not } \\
\text { change my words. If you pass the exam I will buy you a } \\
\text { car }\end{array}$ \\
\hline Situation 13 & راه بصاح بصاح غنعطيك لكتاب & Really, really I will lend you the book. \\
\hline
\end{tabular}

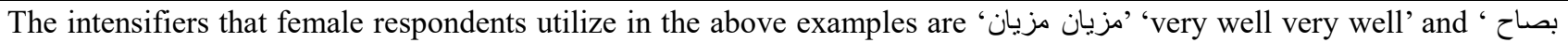
بصاح 'really, really'. Similar to hedging, intensifiers, in the above illustration, do not add any meaningful information to the propositions, but they only enhance and strengthen the word they modify. In the above utterances, the respondents use intensifiers to attain two pragmatic functions: to enhance the self-praising attribution as in situation (6) or to confirm the fulfilment of the promise as in situation (13). 
Furthermore, the results of the study have demonstrated that female subjects tend to use more correct grammatical structures while producing promising utterances. Some examples are presented below:

\begin{tabular}{|c|c|c|}
\hline DCT Item & Moroccan Arabic Promise Utterance & English Translation \\
\hline Situation 18 & الله يهديك. غنوصلك للطبيب & May God guide you. I will drop you to the doctor \\
\hline Situation 4 & الاستكاذ: بغنبلك تو اعدني انه ماعمرك باقي تكذب عليا & $\begin{array}{l}\text { Teacher: I want you to promise me never lie to me again } \\
\text { I promise not to lie again. }\end{array}$ \\
\hline
\end{tabular}

In the first example, the promisor uses Moroccan Arabic to relay her/his promise utterance. However, some phrases like 'اللطبيب' 'May God guide you' 'الله يهديك، '(to the doctor) are borrowed from classical Arabic. In the same vein, the addressee in the second example, chooses to respond in purely Classical Arabic to the teacher's seeking promise utterance. More importantly, during the analysis of the data, the researcher could not find any rough linguistic items in the female respondents' promise utterances.

As far as conversational swearing is concerned, female respondents score a higher percentage, $12 \%$, than men who score $2 \%$. As has been already stated, conversational swearing serves to express a full commitment and sincere intention to fulfil what the promisors pledge. Henceforth, the tendency towards using swearing tactic during promise making evolves out of females' concern about maintaining positive face and sustaining social relationships.

Furthermore, the data presented in this paper has shown a strong dominance of females over self-repetitions that function to confirm the speaker's intention to carry out the promised affair immediately. Such a type of repetitions is generally found to promote perceptions of authenticity (Gershon and Smith (2020). For example,

However, our analysis of the data has revealed that male respondents tend to evoke self-repetitions that communicate negative emotions, like annoyance and irritation (Foolen, 1997). Such a range of repetitions has not been identified among female respondents, which accordingly asserts Lakoff's premise of women's use of super-polite forms.

On accounts of the findings of the current study, it appears that politeness is a key factor that has a say in the linguistic choices of male and female subjects. As has been revealed earlier, male Moroccan high school students do not tend to evoke politeness language while promise making. A possible reason for this is 'social distance', which is best conceived "as a composite of psychologically real factors (status, sex, age, degree of intimacy and closeness) which together determine the overall degree of intimacy and closeness" (Thomas, 2013, p. 128). On this basis, I can argue that the assertive and adversarial language style male subjects have adopted while making promise utterances is attributable to their feeling of closeness to the promisee. It is worth noting that the subjects of this study have been asked to make promises to their friends and siblings, all are relationships that are marked by high levels of connectedness and intimacy. Henceforth, the promisors do not feel the need of developing a super polite language.

Indeed, this study is a good theoretical contribution for the existing body of knowledge on gender-based researches, communicative competence, pragmatics, and issues with regard to intercultural miscommunication. The findings of this study go in line with previous studies, among which we may refer to Huang (2017) that highlights the cultural perspective of speech acts. As far as this study is concerned, the findings reveal that there are different manners of carrying out the speech act of promising by Moroccans. These manners are largely determined by some cultural scripts of the Moroccan society, namely religion and politeness.

Since speech acts are 'culture-specific' (Huang, 2017, 152) and may be performed differently, they are highly likely to yield intercultural and cross-cultural miscommunication. Luckily, these cultural misunderstandings can be overcome through promoting cultural awareness. Gaining knowledge about a specific language is not the only prerequisite for communicating effectively. Henceforth, teachers are invited to teach the vocabulary and grammar of a language along with raising students' awareness to both one's culture and the foreign culture of the taught languages. It is essentially through promoting cultural awareness that the foundation of intercultural communication competence is well-established. Therefore, to assist speakers of divergent languages handle or avoid possible misunderstandings, teachers are required to incorporate the pragmatics and cultural conduct in their teaching of foreign languages.

\section{Conclusion}

On accounts of the findings of the data collected for this study, the researcher outlines the primary strategies Moroccan high school students in public schools opt for to forge promising utterances. These strategies incorporate self-repetitions, conditional promises, conversational swearing, reassurance tactic, self-praising attributions, and preferred adjacency pairing. Studies conducted within the field of speech act of promise manifest that promising is more than cheap speech. Indeed, the analysis of the data asserts that speech acts in general and speech act of promise, in particular, do not only serve to perform actions through uttering clusters of words, but also they seek to communicate significant information 
about the performers of these speech acts and the culture to which they belong. In other terms, speech acts play a significant role in mirroring the values, social norms, behavioral patterns, etc. of a specific culture or sub-culture.

This study has been also designed to figure out whether Moroccan male and female high school students exhibit differences regarding the linguistic choices while making promises. It has been noticed that women tend to use more hedging, super-polite forms, swearing, and empty adjectives than men. Unlike male subjects whose language seems to be assertive, adversarial, and strong, females' speech marks the language of unassertiveness, social connection, intimacy, and rapport. In addition, while issuing their promise utterances, female subjects incline towards enhancing their intentions to carry out the promisee's expectation. This is clearly manifested in the frequent use of swearing tactic and conversational self-repetitions.

\section{References}

Abdel Haleem, M. A. (2004). The Qur'an: A New Translation by M.A.S. Abdel Haleem. New York: Oxford University Press.

Abdel-Jawad, H. R. (2000). A Linguistic and Socio Pragmatic and Cultural Study of Swearing in Arabic. Language, Culture and Curriculum, 13(2), 217-240. https://doi.org/10.1080/07908310008666600

Al Qur'ān al Karīm (the Holy Qur'an)

Al- Saffar, F., H, \& Abbas, N., F. (2015). Promising in American Presidential Discourse. Promising in American Presidential Discourse, 4, 330-344. Retrieved from https://www.researchgate.net/publication/293487000_Promising_in_American_Presidential_Discourse

Anssari-Naim, S. (2016). The Politeness/ Impoliteness Divide: English-Based Theories and Speech Acts Practice in Moroccan Arabic. Valencia: Universidad de Valencia.

Austin, J. (1962). How to do Things with Words. Cambridge: Harvard University Press

Beebe, L.,Takahashi, T., \& Uliss-Weltz, R. (1990). Pragmatic Transfer in ESL Refusals. In R. C. Scarcella, E. Andersen, \& S. D. Krashen (Eds.), Developing Communicative Competence in a Second Language, pp. 55-73. New York, USA: Newbury House.

Beller, S., \& Bender, A. (2017). Speech Act of Promising across Cultures. The International Encyclopedia of Intercultural Communication, 1-10. https://doi.org/10.1002/9781118783665.ieicc0261

Billmyer, K., \& Varghese, M. (2000). Investigating Instrument-Based Pragmatic Variability: Effects of Enhancing Discourse Completion Tests. Applied Linguistics, 21(4), 517-552. https://doi.org/10.1093/applin/21.4.517

Black, H. C. (1991). A Dictionary of Law: Containing Definitions of the Terms and Phrases of American and English Jurisprudence, Ancient, and Modern. New York, NY: Lawbook Exchange.

Brown, P., \& Levinson, S. C. (1987). Politeness: Some Universals in Language Usage. Cambridge, Cambridge University Press. https://doi.org/10.1017/CBO9780511813085

Buchan, N. R., Croson, R. T., \& Solnick, S. (2008). Trust and Gender: An Examination of Behavior and Beliefs in the Investment. Journal of Economic Behavior \& Organization, 68, 3-4, 466-476. https://doi.org/10.1016/j.jebo.2007.10.006

Capraro, V. (2018). Gender Differences in Lying in Sender-Receiver Games: A Meta-Analysis. Judgment and Decision Making, 13(4), 345-355. https://doi.org/10.31234/osf.io/jaewt

Chaudhuri, A., \& Gangadharan, L. (2003). Gender Differences in Trust and Reciprocity, Department of Economics Working Papers Series 875, The University of Melbourne., pp. 1-59. Retrieved from https://ideas.repec.org/p/mlb/wpaper/875.html

Couch, A. L., Susanto, H., \& Chiarini, M. (2007). Modeling Change without Breaking Promises. In Bandara, K., A and Burgess, M. (Eds). Inter-Domain Management: First International Conference on Autonomous Infrastructure, Management and Security, pp. 97-108, Germany, Springer-Verlag Berlin Heidelberg. https://doi.org/10.1007/978-3-540-72986-0_9

Fischer, M. et al. (2017.). Integrating Project Delivery. New Jersey, Wiley. https://doi.org/10.1002/9781119049272

Flagg, B. J. (1998). Was Blind, but Now I See: White Race Consciousness \& the Law. New York: New York University Press.

Foolen, A. (1997). The Expressive Function of Language: Towards A Cognitive Semantic Approach. In Neimeier, S., \& Dirven, R. (Eds.). The Language of Emotions: Conceptualization, Expression, and Theoretical Foundations, pp, 15-32, Amesterdam, John Benjamins Publishing Company. https://doi.org/10.1075/z.85.04foo 
Frederking, B. (2007). The United States and the Security Council Collective Security since the Cold War. London: Routledge. https://doi.org/10.4324/9780203944721

Fried, C. (2015). Contract as Promise: A Theory of Contractual Obligation. Oxford; New York: Oxford University Press. https://doi.org/10.1093/acprof:oso/9780190240158.001.0001

Gershon, R., \& Smith, R. K. (2020). Twice-Told Tales: Self-Repetition Decreases Observer Assessments of Performer Authenticity. Journal of Personality and Social Psychology, 118(2), 307-324. https://doi.org/10.1037/pspi0000183

Gray, J. (1992). Men Are From Mars, Women Are From Venus. New York: Harper Collins.

Grosch, K., \& Rau, H. A. (2017). Gender Differences in Honesty: The Role of Social Value Orientation. Journal of Economic Psychology, 62, 258-267. https://doi.org/10.1016/j.joep.2017.07.008

Heinz, M., Juranek, S., \& Rau, H. A. (2012). Do Women Behave More Reciprocally than Men? Gender Differences in Real Effort Dictator Games. Journal of Economic Behavior \& Organization, 83(1), 105-110. https://doi.org/10.1016/j.jebo.2011.06.015

Howe, N. J. (2015). Better Relationships with Those You Lead: How to Build Productive Working Relationships. Leeming, W.A.: Dr Nicola Howe.

Huang, H. J., \& Hung, Y. (2013). Gender Differences and Behavioral Integrity: From a Social Contract Perspective. Journal of Management \& Organization, 19, 86-100. https://doi.org/10.1017/jmo.2013.6

Huang, Y. (2017). The Oxford Handbook of Pragmatics. Oxford: OUP. Print.

Hutchby, I., \& Wooffitt, R. (1998). Conversation Analysis: Principles, Practices, and Applications. Cambridge, Polity Press in association with Blackwell Publishers Ltd.

Jackson, R. C. (2016). The Pragmatics of Repetition, Emphasis and Intensification (Doctoral dissertation, University of Salford School of Arts and Media, 2016) (pp. 1-287). Salford, UK.

Kim, H. (2002). The Form and Function of Next-Turn Repetition in English Conversation. Language Research, 38(1), 51-81. Retrieved from https://s-space.snu.ac.kr/bitstream/10371/86198/1/3.\%202225610.pdf

Lakoff, R. (1975). Language and Woman's Place. Harper \& Row, Publishers: New York.

Lawlor, K. (2014). Assurance: An Austinian View of Knowledge and Knowledge Claims. Oxford: Oxford University Press. https://doi.org/10.1093/acprof:oso/9780199657896.001.0001

Lazarev, V., \& Pravikova, L. (2003). Men's and Women's Linguistic Conceptualization of Love. In Género, lenguaje y traducción actas del primer seminario internacional sobre género y lenguaje (el género de la traducción $\sim$ la traduccion del género), Ruiz, J. S. (Ed.). pp. 215-233, Valencia, Universitat de València.

Loutfi, A. (2015). Interlanguage Pragmatics: A Study of Moroccan EFL Learners Requests. Germany,Anchor Academic Publishing.

Maltz, D. N., \& Borker, R. A. (1982). A Cultural Approach to Male-Female Miscommunication. In J. J. Gumperz (Ed.), Language and Social Identity. pp. 195-216 Cambridge: Cambridge University Press. https://doi.org/10.1017/CBO9780511620836.013

Meriil, H. J. et al (Eds.) (1892). The American and English Encyclopaedia of Law, 19, Ohio, Werner Printing \& Litho. CO.

Muehlheusser, G. et al. (2015). Gender Differences in Honesty: Groups versus Individuals. Economics Letters, 128, 25-29. https://doi.org/10.1016/j.econlet.2014.12.019

Nurani, M. L. (2009). Methodological Issue in Pragmatic Research: Is Discourse Completion Test a Reliable Data Collection Instrument. Journal of Sosioteknologi, 17(8), 667-678.

Osman, S., \& Jalil, A. (2013, 23-24 October). An Islamic Perspective of Promise and Its Relationship with the Islamic Law of Contract. Paper presented at the ISUFI: International Seminar on Usul Fiqh, Nilai. Retrieved from http://citeseerx.ist.psu.edu/viewdoc/download?doi=10.1.1.953.9945\&rep=rep1\&type=pdf=9[-

Owens, D. (2006). A Simple Theory of Promising. The Philosophical Review, 115(1), 51-77. [Duke University Press, Philosophical Review]. https://doi.org/10.1215/00318108-115-1-51

Searle, J. R. (1969). Speech acts: An essay in the philosophy of language. London: Cambridge University Press. https://doi.org/10.1017/CBO9781139173438

Shimanoff, S., \& 1. Brunak. (1977). Repairs in Planned and Unplanned Discourse. In E. Ochs Keenan and T. Bennett (eds.,) Discourse Across Time and Space (pp. 123-167). Los Angeles: University of Southern California. 
Song, J., Bender, A., \& Beller, S. (2009). Conditional Promises and Threats in Germany, China, and Tonga: Cognition and Emotion. Journal of Cognition and Culture, 9(1-2), 115-139. https://doi.org/10.1163/156853709X414674

Tannen, D. (1990).You Just Don't Understand: Women and Men in Conversation. New York: William Morrow.

Thomas, J. (2013). Meaning in Interaction: An Introduction to Pragmatics. USA, Routledge.

\section{Websites}

Promise. (n.d.). In Oxford Lexico. Retrieved November 11, 2021, from https://www.lexico.com/definition/promise

\section{Appendix A}

$$
\text { اختبار اتمام الخطاب }
$$

\section{Discourse Completion Test}

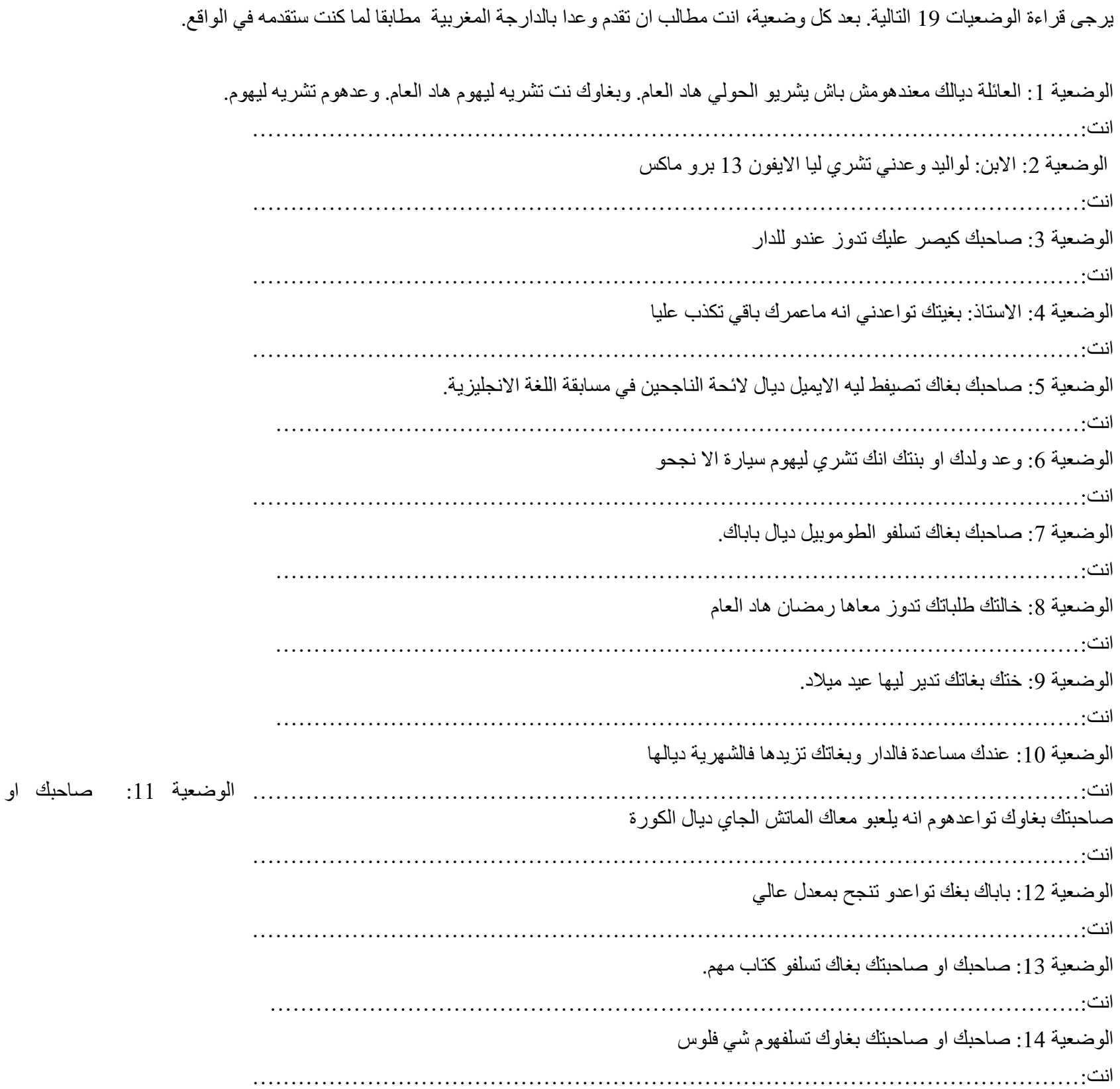




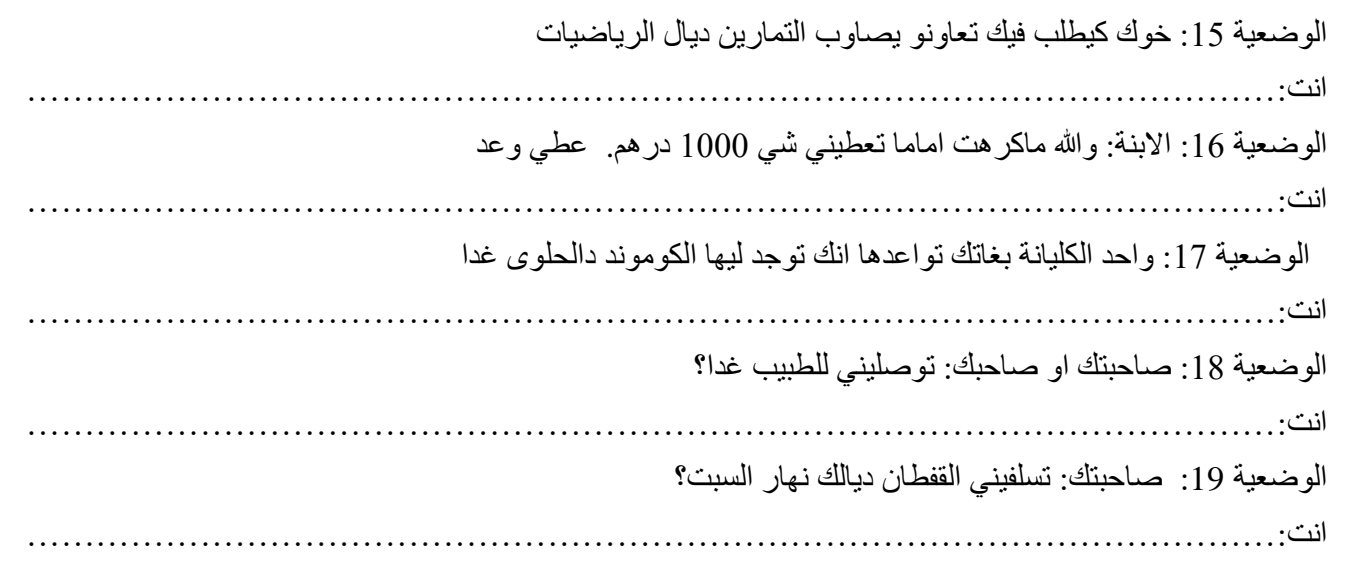

شكرا جزيلا على تعاونكم

\section{Copyrights}

Copyright for this article is retained by the author(s), with first publication rights granted to the journal.

This is an open-access article distributed under the terms and conditions of the Creative Commons Attribution license which permits unrestricted use, distribution, and reproduction in any medium, provided the original work is properly cited. 